\title{
Increased myocardial contractility in short-term Type 1 diabetic patients: an echocardiographic study
}

\author{
L. Thuesen, J.Sandahl Christiansen, N. Falstie-Jensen, C. K. Christensen, K. Hermansen, C. E. Mogensen \\ and P. Henningsen \\ II University Clinic of Internal Medicine and University Department of Cardiology, Aarhus Kommunehospital, Aarhus, Denmark
}

\begin{abstract}
Summary. Cardiac function was investigated by echocardiography in 24 short-term Type 1 diabetic patients with a mean diabetes duration of 7 years (range 4-14 years) during conditions of ordinary metabolic control. Compared to 24 age and sex matched normal control subjects, measurements of myocardial contractility as left ventricular fractional shortening and mean circumferential shortening velocity were increased by $12 \%$ and $20 \%$ respectively. Another 8 Type 1 diabetic patients were examined during conditions of poor (hyperglycaemia and ketosis) and good metabolic control. Following
\end{abstract}

improved glycaemic control, left ventricular fractional shortening and mean circumferential shortening velocity decreased by $16 \%$ and $24 \%$ respectively. Our findings show that shortterm Type 1 diabetes is associated with increased myocardial contractility. Furthermore, this condition is related to the state of metabolic control.

Key words: Echocardiography, left ventricular function, Type 1 diabetes, metabolic control, diabetic cardiopathy.
From studies of blood flow to different organs in shortterm diabetic patients, evidence has accumulated indicating a state of hyperperfusion, at least during conditions of poor metabolic control. Thus an increase in renal plasma flow in diabetic patients with a duration of disease of less than 10 years has been reported by several authors [1-5]. Also in the retina [6], the cerebrum [7], and in the subcutaneous tissue [8], increased blood flow has been observed.

Presently information on cardiac function in shortterm Type 1 diabetes and its possible relation to the state of metabolic control is very scarce.

Therefore we performed echocardiography in 24 short-term Type 1 diabetic patients on standard insulin therapy, and in 8 short-term Type 1 diabetic patients before and after proper metabolic control had been achieved.

\section{Subjects and methods}

\section{Subjects}

Twenty-four Type 1 diabetic patients on ordinary subcutaneous insulin therapy (12 females and 12 males), and 24 age and sex matched normal control subjects, were investigated. Individual clinical data are given in Table 1 . Mean age of diabetic patients was 29 years, with mean duration of disease 8 years. Mean blood glucose profile (mea- sured every second hour for a 24 -h period during in-patient conditions 3-4 days before the echocardiographic examination) was $12.9 \mathrm{mmol} / 1$, mean fasting blood glucose at the day of examination was $10.3 \mathrm{mmol} / 1$ and mean haemoglobin $\mathrm{Alc}(\mathrm{HbAlc}$ ) was $7.2 \%$ (normal range $4.3-5.5 \%$ ). None of the patients had albuminuria or proliferative retinopathy (4 patients had microaneurysms), or other disease than diabetes. Normal control subjects and the diabetic patients were investigated during outpatient conditions.

Further, we examined 8 Type 1 diabetic patients ( 1 woman and 7 men), mean age 31 years. Six of these diabetic patients had newly diagnosed insulin-dependent diabetes mellitus, while the remaining two patients, who had had diabetes for 7 and 12 years, were examined during admission because of malregulation. The patients were examined during the state of poor metabolic control and after 4 to 14 days of improved metabolic control. Individual clinical data are given in Table 2. At the first examination, mean blood glucose was $17.1 \mathrm{mmol} / \mathrm{l}$ and ketone bodies were present in the urine, but none were acidotic. Three patients had begun insulin therapy at the examination. At the second examination, mean blood glucose was $7.6 \mathrm{mmol} / 1$, and there was no ketonuria. Both examinations were performed during admission from 09.00 to 12.00 hours.

All patients gave informed consent to the investigation, which was in accordance with the declaration of Helsinki.

\section{Echocardiography}

After 10 min of rest in a supine position, blood pressure was measured using a sphygomanometer with Korotkoff's phase 1 and 5 sounds indicating systolic and diastolic blood pressure respectively. Two-dimensional echocardiography and M-mode echocardiography were performed with a simultanous electrocardiogram. The echocardiographic equipment used were: an ATL 315A video display, an ATL 850A 
Table 1. Clinical data in 24 short-term Type 1 diabetic patients

\begin{tabular}{|c|c|c|c|c|c|c|c|}
\hline Patient/sex & $\begin{array}{l}\text { Age } \\
\text { (years) }\end{array}$ & $\begin{array}{l}\text { Body mass } \\
\text { index } \\
\left(\mathrm{kg} / \mathrm{m}^{2}\right)\end{array}$ & $\begin{array}{l}\text { Duration } \\
\text { of disease } \\
\text { (years) }\end{array}$ & $\begin{array}{l}\text { Blood glucose } \\
\text { profile } \\
(\mathrm{mmol} / \mathrm{l})\end{array}$ & $\begin{array}{l}\text { Fasting blood } \\
\text { glucose } \\
(\mathrm{mmol} / \mathrm{l})\end{array}$ & $\begin{array}{l}\text { HbAlc } \\
(\%)\end{array}$ & Retinopathy \\
\hline $2 \mathrm{M}$ & 37 & 21.7 & 3 & 17.4 & 10.8 & 8.8 & - \\
\hline $3 F$ & 33 & 21.2 & 7 & 16.2 & 8.1 & 7.5 & - \\
\hline $4 \mathrm{~F}$ & 26 & 20.8 & 15 & 10.6 & 19.5 & 6.7 & + \\
\hline $7 \mathrm{M}$ & 34 & 26.0 & 12 & 8.3 & 9.3 & 7.1 & + \\
\hline $8 \mathrm{M}$ & 38 & 22.6 & 4 & 8.9 & 11.1 & 6.4 & - \\
\hline $9 \mathrm{~F}$ & 24 & 27.5 & 8 & 10.9 & 7.5 & 9.2 & - \\
\hline $10 \mathrm{~F}$ & 22 & 24.7 & 11 & 14.9 & 12.2 & 7.3 & - \\
\hline $11 \mathrm{M}$ & 22 & 23.5 & 8 & 16.2 & 6.7 & 9.0 & + \\
\hline $12 \mathrm{M}$ & 30 & 24.0 & 12 & 15.0 & 5.2 & 5.5 & - \\
\hline $13 \mathrm{~F}$ & 29 & 18.5 & 7 & 12.8 & 19.0 & 7.7 & - \\
\hline $18 \mathrm{M}$ & 23 & 21.1 & 10 & 15.0 & 10.3 & 9.7 & - \\
\hline $19 \mathrm{M}$ & 38 & 23.5 & 12 & 13.6 & 12.5 & 7.3 & - \\
\hline $20 \mathrm{M}$ & 25 & 24.5 & 1 & 16.1 & 16.1 & 7.6 & - \\
\hline $21 \mathrm{~F}$ & 24 & 21.6 & 5 & 14.1 & 13.3 & 7.1 & - \\
\hline $22 \mathrm{~F}$ & 27 & 21.0 & 7 & 8.8 & 4.9 & 5.8 & - \\
\hline $23 \mathrm{~F}$ & 21 & 21.5 & 5 & 17.2 & 8.8 & 8.0 & - \\
\hline $24 \mathrm{~F}$ & 44 & 20.0 & 10 & 9.9 & 9.5 & 5.9 & - \\
\hline Mean & 29.2 & 22.7 & 8 & 12.9 & 10.3 & 7.2 & \\
\hline $1 \mathrm{SD}$ & 6.4 & 2.2 & 3.8 & 3.0 & 4.3 & 1.1 & \\
\hline
\end{tabular}

(F) and (M) signify female and male. Body mass index: (weight in $\mathrm{kg}$ ) $/$ (height in meters) $^{2}$. Blood glucose profile: mean of 12 determinations during $24 \mathrm{~h} .(+/-)$ signify presence or absence of retinal microaneurysms

Table 2. Clinical data in 8 Type 1 diabetic patients during poor metabolic control (PMC) and following improved metabolic control (IMC)

\begin{tabular}{|c|c|c|c|c|c|c|c|c|}
\hline \multirow[t]{2}{*}{ Patient } & \multirow[t]{2}{*}{$\begin{array}{l}\text { Sex } \\
\text { (female/male) }\end{array}$} & \multirow[t]{2}{*}{$\begin{array}{l}\text { Age } \\
\text { (years) }\end{array}$} & \multirow{2}{*}{$\begin{array}{l}\text { Duration } \\
\text { of disease } \\
\text { (years) }\end{array}$} & \multirow{2}{*}{$\begin{array}{l}\text { Body mass } \\
\text { index } \\
\left(\mathrm{kg} / \mathrm{m}^{2}\right)\end{array}$} & \multicolumn{2}{|c|}{$\begin{array}{l}\text { Mean } \\
\text { blood glucose }\end{array}$} & \multicolumn{2}{|c|}{$\begin{array}{l}24-h \\
\text { urinary ketone bodies }\end{array}$} \\
\hline & & & & & $\begin{array}{l}\text { PMS } \\
(\mathrm{mmol} / \mathrm{l})\end{array}$ & $\begin{array}{l}\text { IMC } \\
(\mathrm{mmol} / \mathrm{l})\end{array}$ & $\begin{array}{l}\text { PMC } \\
(+/-)\end{array}$ & $\begin{array}{l}\text { IMC } \\
(+/-)\end{array}$ \\
\hline I & male & 34 & 7 & 23.3 & 15.7 & 4.2 & + & - \\
\hline II & male & 22 & 0 & 17.2 & 18.9 & 8.4 & + & - \\
\hline III & male & 30 & 0 & 21.3 & 14.7 & 6.3 & +++ & - \\
\hline VI & male & 40 & 0 & 22.1 & 12.0 & 6.9 & + & - \\
\hline VII & male & 36 & 0 & 21.9 & 20.4 & 12.5 & $++t$ & - \\
\hline VIII & male & 38 & 12 & 23.6 & 16.5 & 8.2 & + & - \\
\hline Mean & & 30.9 & & 21.8 & 17.1 & 7.6 & & \\
\hline $1 \mathrm{SD}$ & & 7.4 & & 2.1 & 2.9 & 2.4 & & \\
\hline
\end{tabular}

Body mass index: (weight in $\mathrm{kg}$ )/(height in meters) ${ }^{2}$. Mean blood glucose: mean of 6 measurements

real time scan controller, an ATL pulsed echo 600B (Advanced Technology Laboratories Inc., USA), and a Honeywell 1856 visiocorder (Honeywell, USA). The two-dimensional echo was used to ensure absence of wall asynergy and localization of optimal M-mode measurements of the internal end-systolic diameter (LVIDs) and the internal end-diastolic diameter (LVIDd) of the left ventricle just below the mitral valve. Left ventricular ejection time (LVET) was measured from the opening to the closure of the aortic valve [9]. Mean of 5 expiratory cardiac cycles was used. Paperspeed was $50 \mathrm{~mm} / \mathrm{sec}$.

\section{Definitions}

End-systolic volume (SV) and end-diastolic volume (DV) of the left ventricle were calculated as described by Teichholtz [10]: ventricular volume: $\frac{7}{2.4+D} \times D^{3}$, where $D$ is the left ventricular internal short di-

ameter; cardiac output: $($ DV-SV $) \times$ heart rate; fractional shortening

$(\mathrm{FS} \%): \frac{\text { LVIDd-LVIDs }}{\text { LVIDd }} \%$; mean velocity of circumferential shorten-

ing (Vef): FS\%/LVET. To eliminate confounding differences in height and weight of the diabetic patients and the control subjects, parameters, including ventricular volumes and diameters, were corrected for body surface area using the formula of Du Bois. 
Table 3. Haemodynamic and echocardiographic parameters in 24 short-term Type 1 diabetic patients

\begin{tabular}{|c|c|c|c|c|c|c|}
\hline Patient & $\begin{array}{l}\text { Mean arterial } \\
\text { blood pressure } \\
\text { mmHg }\end{array}$ & $\begin{array}{l}\text { Heart rate } \\
\text { (beats } / \text { min) }\end{array}$ & $\begin{array}{l}\text { Diastolic } \\
\text { diameter } \\
\left(\mathrm{mm} / \mathrm{m}^{2}\right)\end{array}$ & $\begin{array}{l}\text { Systolic } \\
\text { diameter } \\
\left(\mathrm{mm} / \mathrm{m}^{2}\right)\end{array}$ & $\begin{array}{l}\text { Ejection } \\
\text { time (ms) }\end{array}$ & $\begin{array}{l}\text { Mean circumferential } \\
\text { shortening velocity } \\
\text { (circumf./s) }\end{array}$ \\
\hline 2 & 85 & 81 & 28 & 17 & 286 & 1.34 \\
\hline 3 & 83 & 74 & 26 & 17 & 263 & 1.27 \\
\hline 4 & 78 & 75 & 30 & 18 & 269 & 1.47 \\
\hline 7 & 90 & 76 & 23 & 14 & 288 & 1.31 \\
\hline 8 & 70 & 89 & 26 & 19 & 252 & 1.09 \\
\hline 9 & 83 & 85 & 27 & 18 & 288 & 1.18 \\
\hline 10 & 90 & 86 & 25 & 17 & 250 & 1.22 \\
\hline 11 & 80 & 67 & 29 & 18 & 288 & 1.25 \\
\hline 12 & 80 & 62 & 28 & 17 & 327 & 1.19 \\
\hline 13 & 97 & 98 & 27 & 15 & 220 & 1.95 \\
\hline 18 & 80 & 82 & 31 & 19 & 287 & 1.37 \\
\hline 19 & 97 & 68 & 27 & 17 & 294 & 1.19 \\
\hline 20 & 90 & 60 & 28 & 19 & 308 & 1.05 \\
\hline 21 & 90 & 72 & 31 & 18 & 317 & 1.32 \\
\hline 22 & 93 & 68 & 31 & 21 & 311 & 1.03 \\
\hline 23 & 93 & 48 & 27 & 17 & 317 & 1.12 \\
\hline 24 & 80 & 83 & 29 & 17 & 250 & 1.70 \\
\hline Mean & 86 & 74 & 27.3 & 16.7 & 288 & 1.32 \\
\hline $1 \mathrm{SD}$ & 7.1 & 12.4 & 2.4 & 2.3 & 35 & 0.23 \\
\hline \multicolumn{7}{|c|}{ Normal control subjects $(n=24)$} \\
\hline Mean & 88 & 66 & 27.9 & 18.5 & 311 & 1.10 \\
\hline
\end{tabular}

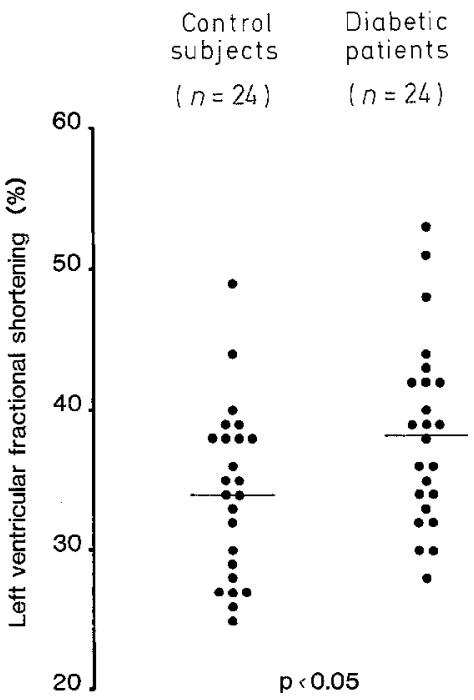

Fig. 1. Left ventricular fractional shortening $(\%)$ in 24 short-term Type 1 diabetic patients and in 24 age and sex-matched normal control subjects

\section{Calculations and statistics}

The echocardiographic recordings were described without knowledge of the status of the subject examined. The recordings in the group of diabetic patients investigated before and during improved metabolic control were described in pairs to ensure identical levels in measuring the diameter of the left ventricle.

Statistical evaluation was performed using the two-tailed paired and non-paired Student's t-test. Data are given as mean and range, or as mean $\pm 1 \mathrm{SD}$, with a level of significance $p<0.05$.

\section{Results}

Results from the echocardiographic examination in 24 short-term diabetic patients and 24 normal control subjects are shown in Table 3. Mean arterial blood pressure was not significantly different in the two groups, while heart rate was $12 \%(p<0.025)$ higher in the diabetic patient group. End diastolic diameter did not show differences between the groups but end systolic diameter was significantly lower in the diabetic patient group ( $p<$ $0.05) . \mathrm{FS} \%$ was $12 \%(p<0.01)$ higher in the diabetic patient group $(38 \pm 7 \%)$ than in the group of normal control subjects $(34 \pm 6 \%)$ (Fig. 1 ). Also Vcf was significantly increased among the diabetic patients $(23 \%)$ $(p<0.005)$. Calculation of ventricular volumes showed an insignificant increase in stroke volume in the diabetic patient group. Because of higher heart rate in the diabetic patient group, cardiac output (cardiac index) was found significantly higher $(p<0.01)$ in this group $\left(3.2 \pm 0.71 / \mathrm{min} \times \mathrm{m}^{2}\right)$ as compared to the group of nor- 
Table 4. Haemodynamic and echocardiographic parameters in 8 Type 1 diabetic patients during poor metabolic control (PMC) and following improved metabolic control (IMC)

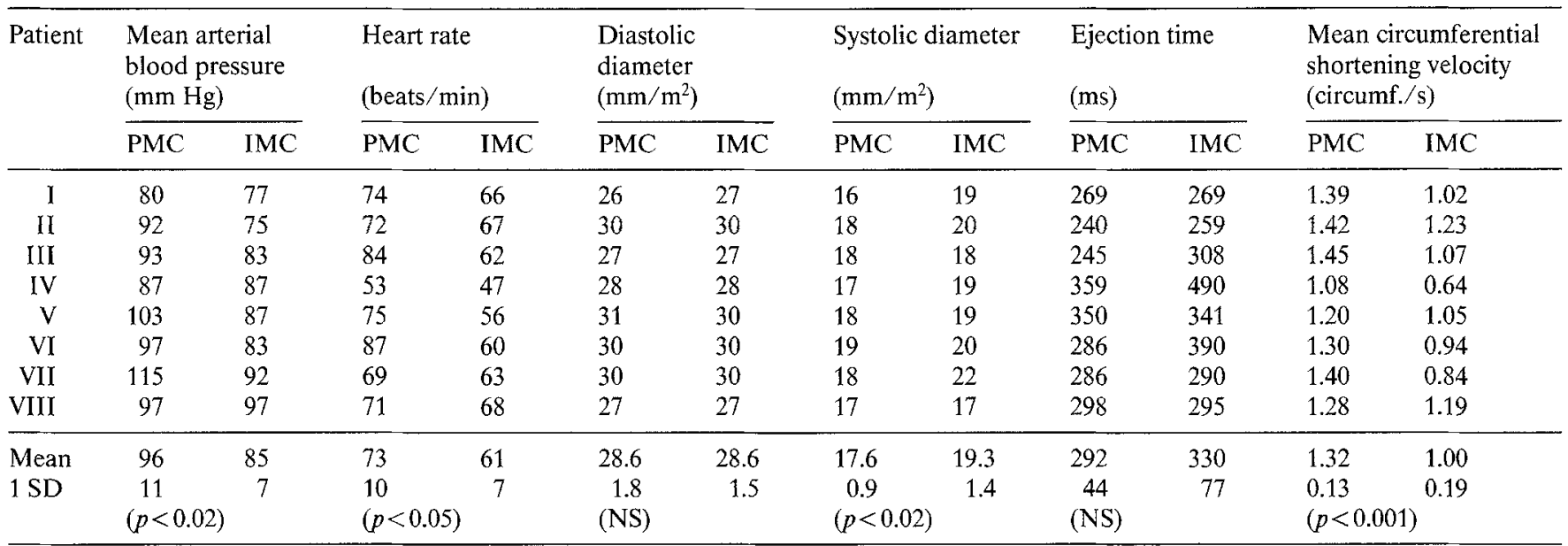

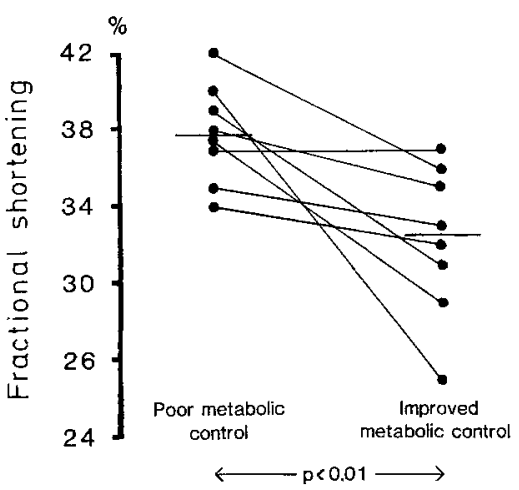

Fig. 2. Left ventricular fractional shortening (\%) in 8 Type 1 diabetic patients during poor and following improved metabolic control

mal control subjects $\left(2.6 \pm 0.51 / \mathrm{min} \times \mathrm{m}^{2}\right)$. No significant correlation was found between either $\mathrm{FS} \%$, Vcf or cardiac output and HbAlc and blood glucose.

Results from the paired observations in the 8 Type 1 diabetic patients during poor and following improved metabolic control are shown in Table 4. Both heart rate and mean arterial blood pressure decreased significantly following improved metabolic control. End diastolic diameter was unchanged, while end systolic diameter increased significantly $(p<0.02)$ following improved control. The parameters of contractility decreased significantly following improved glycaemic control (FS $\%$ from $38 \pm 3 \%$ to $32 \pm 4 \%(p<0.01$ ) (Fig. 2 ) and Vcf by $24 \%(p<0.001)$ (Table 4$)$. Calculation of ventricular volumes showed unchanged diastolic volume, but significantly increased systolic volume and significantly decreased stroke volume, together with decreased heart rate resulting in significantly $(p<0.01)$ reduced cardiac output (index) following improved metabolic control (from $3.5 \pm 0.7 \mathrm{l} / \mathrm{min} \times \mathrm{m}^{2}$ to $2.7 \pm 0.5$ $1 / \min \times \mathrm{m}^{2}$ ).

Day to day variation was assessed in 8 normal control subjects. The percent mean variation was: FS\%
$8.2 \pm 5.9 \%$, Vcf $10.0 \pm 8.1 \%$ and cardiac index $9.6 \pm$ $5.5 \%$.

\section{Discussion}

The present study demonstrates clearly that short-term (less than 15 years duration) uncomplicated Type 1 diabetes is associated with increased fractional shortening and increased mean circumferential shortening velocity of the left ventricle, and that this enhanced myocardial contractility is related to metabolic control.

Necropsy studies have suggested a specific diabetic cardiopathy [11], and evaluation of cardiac function by non-invasive techniques such as systolic time intervals and echocardiography have provided evidence of subclinical cardiomyopathy in diabetic patients [12-15]. In studies where potentially important factors such as age of the patient, duration of diabetes and presence of clinical microvascular complications have been considered, the prevalent finding have been signs of impaired left ventricular function in patients with long duration of disease and presence of severe microvascular complications $[12,14]$. Impaired cardiac function has been suggested on the basis of an increased pre-ejection period left ventricular ejection time - ratio [12], disturbed relation between mitral valve movement and left ventricular wall movement [14] and by decreased fractional shortening [16]. On the other hand, pre-ejection period - left ventricular ejection time - ratio has been found within normal limits in short-term uncomplicated diabetes [12].

The present finding of increased myocardial contractility is not inconsistent with the above mentioned reports, since we have been dealing exclusingly with rather short-term patients without signs of microvascular disease except for a few cases showing a light degree of background retinopathy. Thus a longitudinal prospective study would be needed in order to further elucidate the relationship between diabetes duration, clini- 
cal microvascular complications and cardiac function in Type 1 diabetes.

The pathogenesis of increased myocardial contractility cannot be deduced from the present study. Myocardial contractility may be enhanced due to elevated sympathetic activity [17], altered myocardial metabolism, or be secondary to increased peripheral circulatory demands. Further studies will be required in order to identify the factors and mechanisms behind the increased contractility.

While FS $\%$ and Vcf are reliable parameters of myocardial contractility [9], there are considerable problems in determining left ventricular volumes and cardiac output from measurement of the short diameter of the left ventricle [18] as described by Teichholz [10]. However, we think our observation of increased heart rate, increased contractility and identical left ventricular internal diastolic diameter in the diabetic patient group compared to the normal control subjects is highly suggestive of increased cardiac output in short-term uncomplicated diabetes. In this context it is of particular interest that our preliminary report, which suggests significant alterations in cardiac output secondary to changes in metabolic control in Type 1 diabetic patients [19], has recently been confirmed by a Xenon-wash out technique [20]. Our suggestion of cardiac output in short-term Type 1 diabetic patients would be completely compatible with our knowledge of increased blood flow to the kidneys $[2-4]$, the retina $[6,21]$ and the peripheral tissues $[8,22]$ of these patients. Until now there are no other reports comparing indices of cardiac output in Type 1 diabetic patients with normal subjects, and the present suggestion based on indirect meassurements awaits confirmation.

From our finding of normalization of myocardial contractility following improved glycaemic control it can be concluded, however, that the degree of metabolic control is an important factor in this condition. Further, this finding might be of clinical relevance since haemodynamic changes such as localized hyperperfusion has been suggested as an important component in the development of diabetic microvascular disease [23].

Acknowledgement. This study was supported by Landsforeningen for Sukkersyge and the Danish Heart Association.

\section{References}

1. Mogensen CE (1972) Kidney function and glomerular permeability to macromolecules in juvenile diabetes. Dan Med Bul 19 (Suppl 3): 1-40

2. Christiansen JS, Gammelgaard J, Frandsen M, Parving H-H (1981) Increased kidney size, glomerular filtration rate and renal plasma flow in short-term insulin dependent diabetics. Diabetologia 20: 451-456

3. Puig JG, Antón FM, Grande C (1981) Relation of kidney size to kidney function in early insulin-dependent diabetes. Diabetologia $21: 363-367$
4. Nyberg G, Granerus G, Aurell M (1982) Renal extraction ratios for Cr-EDTA, PAH and glucose in early insulin-dependent diabetic patients. Kidney Int 21: 706-708

5. Christiansen JS, Gammelgaard J, Tronier B, Svendsen PA, Parving $\mathrm{H}-\mathrm{H}$ (1982) Kidney function and size in diabetics before and during initial insulin treatment. Kidney Int 21: 683-688

6. Kohner EM, Hamilton AM, Saunders SJ, Sutcliffe BA, Bulpitt CJ (1975) The retinal blood flow and diabetes. Diabetologia 11: $27-33$

7. Dandona P, Wollard ML, James IM, Newburry P, Beckett AG (1979) Instability of cerebral blood flow in insulin-dependent diabetics. Lancet 2: 1203-1205

8. Gundersen HJG (1974) Peripheral blood-flow and metabolic control in juvenile diabetes. Diabetologia 10:225-231

9. Feigenbaum H (1981) Echocardiography, 3rd eds. Lea and Fibiger, Philadelphia, pp 119-221

10. Teichholz LE, Kreulen T, Herman MV, Gorlin R (1976) Problems in echocardiographic volume determinations: echocardiographicangiographic correllations in the presence or absence of asynergy. Am J Cardiol 37: 7-11

11. Ledet T (1976) Diabetic cardiopathy. Quantitative histological studies of the heart from young juvenile diabetics. Acta Pathol Microbiol Scand 84: 421-428

12. Shapiro LM, Leatherdale BA, Mackinnon J, Fletcher RF (1981) Left ventricular function in diabetes mellitus. Br Heart $\mathrm{J} 45$ : $129-132$

13. Sultan Ahmed S, Jaferi GA, Narang RM, Regan TJ (1975) Preclinical abnormality of left ventricular function in diabetes mellitus. Am Heart J 89: 153-158

14. Sanderson JE, Brown DJ, Rivellese A, Kohner E (1978) Diabetic cardiopathy? An echocardiographic study of young diabetics. $\mathrm{Br}$ Med J 1: 404-407

15. Seneviratne BIB (1977) Diabetic cardiopathy: the preclinical phase. Br Med J 1: 1444-1446

16. Lababidi ZA, Goldstein DE (1983) High prevalence of echocardiographic abnormalities in diabetic youths. Diabetes Care 6: $18-22$

17. Christensen NJ (1974) Plasma norepinephrine and epinephrine in untreated diabetics during fasting and after insulin administration. Diabetes 25 (Suppl 2): 903-908

18. Ludbrook P, Karliner JS, Peterson K, Leopold G, O'Rourke RA (1973) Comparison of ultrasound and cineangiographic measurements of left ventricular performance in patients with and without wall motion abnormalities. Br Heart J 35: 1026-1032

19. Thuesen L, Christiansen JS, Jensen NF (1984) Reduced cardiac output following improved metabolic control in Type 1 (insulindependent) diabetic patients. Diabetologia 27:338 A

20. Mathiesen ER, Hilsted J, Feldt-Rasmussen B, Bonde-Petersen F, Christensen NJ, Parving H-H (1985) Effect of metabolic control on haemodynamics in short-term insulin-dependent diabetic patients. Diabetes (in press)

21. Soeldner JS, Christacopoulus PD, Gleason RE (1976) Mean retinal circulation time as determined by flourescein angiography in normal, prediabetic and chemical-diabetic subjects. Diabetes 25 (Suppl 2): 903-908

22. Häggendal E, Steen B, Svanberg A (1970) Blood-flow in subcutanous tissue in patients with diabetes mellitus. Acta Med Scand 187: 49-53

23. Parving $\mathrm{H}-\mathrm{H}$, Viberti GC, Keen $\mathrm{H}$, Christiansen JS, Lassen NA (1983) Hemodynamic factors in the genesis of diabetic microangiopathy. Metabolism 32: 943-949

Received: 2 January 1985

and in revised form: 3 September 1985

Dr. Leif Thuesen

II University Clinic of Internal Medicine

Kommunehospitalet

DK-8000 Aarhus C

Denmark 